\title{
Discrepant distribution of big endothelin (ET)-1 and ET receptors in the pulmonary artery
}

\author{
H. Takahashi, S. Soma, M. Muramatsu, M. Oka, H. lenaga, Y. Fukuchi
}

\begin{abstract}
Discrepant distribution of big endothelin (ET)-1 and ET receptors in the pulmonary artery. H. Takahashi, S. Soma, M. Muramatsu, M. Oka, H. Ienaga, Y. Fukuchi. (C) ERS Journals Ltd 2001.

ABSTRACT: Since pulmonary vasculature is complex in terms of regional difference in structure and function, it is important to understand the site of endothelin (ET) synthesis and the distribution of the ET system along the axial pathways of pulmonary artery.

The expression of big ET-1, ET converting enzyme (ECE) and ETA receptors were examined in rat pulmonary arteries under normal and hypoxic conditions using an immunohistochemical method and Northern blot analysis.

In normal conditions, big ET-1 was expressed in the intima and media of pulmonary arteries with a predominant distribution in the distal segments and a preferential localization in the media, while ETA receptors were dominantly expressed in the proximal segments. ECE was constitutively expressed in the intima and media. Following exposure to hypoxia, messenger ribonucleic acid (mRNA) expression of ET-1 and ETA receptors were up-regulated by two-fold and immunoreactivities for big ET-1, ECE, and ETA receptors significantly increased by two to five-fold in the distal segments.

Smooth muscle cells are an important source of endothelin-1 in the pulmonary artery. The distribution of big endothelin-1 and endothelin A receptors in pulmonary arteries was discrepant in normal conditions while their expression concomitantly increased in the distal segments in hypoxic conditions. This heterogeneity may play an important role in the regulation of pulmonary vascular tone.

Eur Respir J 2001; 18: 5-14.
\end{abstract}

Dept of Respiratory Medicine, Juntendo University, School of Medicine, Tokyo, Japan.

Correspondence: H. Takahashi, Clinic, Personnel Division, Mitsui \& Co, Ltd, 1-2-1 Otemachi, Chiyoda-Ku, Tokyo 100-0004, Japan.

Fax: 81332859152

Keywords: Endothelial cell endothelin converting enzyme hypoxic pulmonary hypertension smooth muscle cell

Received: August 282000

Accepted after revision March 22001
Endothelins (ETs) and their receptors are abundantly expressed in the lung and postulated to play an important role in the regulation of pulmonary vascular tone. ET-1, a potent vasoconstrictor and smooth muscle mitogen composed of 21 amino acids, is synthesized from big ET-1 by a specific cleavage at $\operatorname{Trp}^{21}-\mathrm{Val}^{22}$ by ET converting enzyme (ECE) $[1,2]$. The actions of ET-1 are mediated by two different receptors, ETA and ETB receptors [1, 2]. ETA receptors are found in pulmonary vascular smooth muscle cells and mediate smooth muscle contraction and the proliferation of smooth muscle cells and fibroblasts, while ETB receptors are expressed in endothelial cells (ETB1 receptors) and smooth muscle cells (ETB2 receptors) and cause either relaxation or contraction, respectively $[2,3,4]$. Since the pulmonary vascular bed is complex in terms of regional differences in both structure and function, it is important to know about localization and distribution of ET-1 and ET receptors. Although it is known that ET-1 is expressed in various cells including endothelial cells, epithelial cells, smooth muscle cells, and tissue macrophages in the lung $[2,5,6]$, there are few studies showing the distribution of ET-1 and
ECE expression along the axial pathways of the pulmonary artery.

The over-expression of the messenger ribonucleic acid (mRNA) for ET-1, ETA and ETB receptors, and the overproduction of the ET-1 peptide in whole lung have been demonstrated in an experimental model of hypoxic pulmonary hypertension [6-11]. Furthermore, blocking ETA receptors with selective antagonists attenuates the rise in pulmonary arterial pressure and the development of vascular remodelling associated with chronic hypoxia [12-14]. While it is obvious that ET-1 and ET receptors play important roles in the pathophysiology of hypoxic pulmonary hypertension, it is uncertain whether ET-1 synthesis is increased in pulmonary resistance arteries, the critical site of pulmonary blood flow regulation, and rapid adaptation and remodelling under hypoxic condition.

In the present study, the localization and distribution of big ET-1 and ECE in the rat pulmonary artery was investigated, and temporal changes in the expression after exposure to hypoxia in order to clarify the site of ET-1 synthesis under normal and hypoxic conditions. The distribution of big ET-1 and ECE was also compared with that of ETA receptors in 
pulmonary arteries to explore the interaction of ET-1 and ET receptors in normal pulmonary circulation and in hypoxic pulmonary hypertension.

\section{Materials and methods}

\section{Animals}

The methods used to isolate rat lungs were identical to those previously reported except that special attention was paid to keeping the animals under hypoxic conditions prior to the lung preparation, since lung ET-1 mRNA expression has been reported to decrease rapidly in rats exposed to chronic hypoxic pulmonary hypertension after a brief exposure to normoxia [4, 15]. Briefly, adult male Sprague-Dawley rats ( 8 weeks old, $260-280 \mathrm{~g}$ ) were placed for $0.5,3,7$, or 14 days in a specially designed hypobaric chamber (oxygen concentration reduced to $10 \%$ ). To minimize exposure to normoxia, rats raised in the hypobaric chamber were transferred to and kept in a chamber filled with $10 \%$ oxygen $/ 90 \%$ nitrogen just before lung preparation. Age-matched controls were maintained in room air. The lungs were isolated from rats after the intraperitoneal administration of $60 \mathrm{mg}$ pentobarbital and intracardiac injection of $100 \mathrm{U}$ heparin. Cannulas were inserted into the pulmonary artery and left atrium, and the lungs were perfused at $36 \mathrm{cmH}_{2} \mathrm{O}$ through the pulmonary arterial cannula with phosphate-buffered saline (PBS). The right lung was removed at the main bronchus, frozen in liquid nitrogen, and stored at $-80^{\circ} \mathrm{C}$ until extraction of total cellular RNA. The left lung was perfused with $4 \%$ paraformaldehyde (PFA), inflated by infusion of 4\% PFA through the cannula inserted in the trachea, and fixed in $4 \%$ PFA overnight at $4{ }^{\circ} \mathrm{C}$. After the PFA was removed, the lung tissue was filled with optimal cutting temperature (OCT) compound through the tracheal cannula, embedded into OCT compound, and stored at $-80^{\circ} \mathrm{C}$ until it was used for immunohistochemical studies. The development of hypoxic pulmonary hypertension was determined by the weight ratio of the right ventricle over the left ventricle plus septum (RV/ $\mathrm{LV}+\mathrm{S}$ ), as previously described [16]. The number of animals in each group was four to six.

\section{Immunohistochemistry}

To detect ET-1 synthesis in the pulmonary vasculature, anti-big ET-1 antibody and anti-ECE-1 antibody instead of anti-ET-1 antibody was used, because immunostaining using three kinds of anti-ET-1 antibodies purchased from different companies showed a certain degree of nonspecific staining (data not shown). Frozen sections $(4 \mu \mathrm{m})$ cut in a cryostat at $-20{ }^{\circ} \mathrm{C}$ were mounted on slides, and incubated with $10 \%$ normal goat serum to reduce nonspecific binding of second antibodies. Tissue sections used for ECE staining were pretreated by placing the slides with $0.01 \mathrm{M}$ citrate buffer in an autoclave at $120^{\circ} \mathrm{C}$ for $10 \mathrm{~min}$ before incubation. The serum was removed and the sections were incubated with rabbit antihuman big ET-1 polyclonal antibody (IBL Inc., Gumma, Japan) at $10, \mu \mathrm{g} \cdot \mathrm{mL}^{-1}$, antirat ECE monoclonal antibody (AEC27-121, a gift from T.K. Sankyo Co. Ltd. Tokyo, Japan) [17] at $60 \mu \mathrm{g} \cdot \mathrm{mL}^{-1}$, or rabbit anti-rat ETA receptor polyclonal antibody (IBL Inc., Gumma Prefecture, Japan) at $5 \mu \mathrm{g} \cdot \mathrm{mL}^{-1}$ for $12 \mathrm{~h}$ at $4{ }^{\circ} \mathrm{C}$. In addition, monoclonal antibodies against rat vascular cell adhesion molecule-1 (VCAM-1) $\left(5 \mu \mathrm{g} \cdot \mathrm{mL}^{-1}\right.$, Santa Cruz Biotechnology, Inc., Santa Cruz, CA, USA) and human $\alpha$-smooth muscle (SM) actin $\left(0.2 \mu \mathrm{g} \cdot \mathrm{mL}^{-1}\right.$, DAKO, Glostrup, Denmark) were used as an endothelial marker and smooth muscle marker, respectively. The sections were further incubated with a biotinylated goat antirabbit immunoglobulin (Ig)-G antibody (diluted 1:100) for $30 \mathrm{~min}$, then with the avidin-biotin-peroxidase complex (diluted 1:100, Vector Laboratories, Inc., Burlingame, CA, USA) for $30 \mathrm{~min}$. Subsequently, the immunoperoxidase colour reaction was developed by incubation for $5 \mathrm{~min}$ in Tris/HC1 containing $0.05 \% 3,3^{\prime}$ diaminobenzidine tetrahydrochloride and $0.01 \%$ hydrogen peroxide. Negative controls were prepared with rabbit nonimmune serum instead of primary antibody or by omitting steps in the avidinbiotin peroxidase complex procedure. The sections were counterstained with methyl green (staining for big ET-1, VCAM-1, ETA receptor, and $\alpha-\mathrm{SM}$ actin) or haematoxylin (staining for ECE). Serial sections were stained with elastic van Gieson staining for the accurate identification of arteries and veins by the presence or absence of internal elastic lamina [18]. For each rat, pulmonary arteries were grouped according to the external diameter (ED): $60-200 \mu \mathrm{m}, 200-500 \mu \mathrm{m}$, and $500-1000 \mu \mathrm{m}$. The sections were examined by light microscopy without knowledge of the treatment group by two specific individuals. The intensity of immunostaining was graded semiquantitatively $0-3$ : grade 0 , no staining; grade 1 , focal staining or weak staining; grade 2, diffuse moderate staining; and grade 3 , strong staining [4]. To assess changes in the expression of big ET-1, ECE, and $\alpha$-SM actin after exposure to hypoxia, the immunostaining grades of the pulmonary arteries were estimated in lung sections from each animal. In each animal, at least 30 arteries (60-200 $\mu \mathrm{m}$ ED) associated with terminal bronchioles or lying within the acinus, and 3-5 arteries larger than $500 \mu \mathrm{m}$ ED were analysed. In each section, all fields were evaluated consecutively. The data were calculated for each group.

\section{Northern blot analysis}

Northern blot analysis was carried out as previously described [19]. The complementary deoxyribonucleic acid (cDNA) probes for rat ET-1, ECE-1, and ETA receptor were synthesized by reverse transcriptase (RT)-polymerase chain reaction (PCR). The primers used for PCR were as follows: sense 5'GCGAT CCTTGAAAGACTTAC-3', antisense 5'-CTCGG TTGTGTATCAACTTC-3' for preproET-1; sense 5' -TTCCAGCTGGAATCCTGCAG-3', antisense5'GTTCTGAGAACTCCTTGGAG-3' for ECE-1; and sense 5'TGTTGCTGTTGTCACCAGTCC-3', 
antisense 5'-GAGCGCAGCTGCTGCGTGACCG3' for ETA receptor [20-22]. Ten micrograms of total cellular RNA extracted from the lung was electrophoresed on $1 \%$ agarose gels, transferred to nylon membranes (HiBond N, Amersham Japan, Tokyo, Japan), and the membranes were hybridized with the cDNA probes. The bands hybridized with the probes were quantitated by densitometry using a computerassisted image analyser (BAStation; Scanalytics, Billerica, MA, USA). After probing with ET-1, ECE-1, or ETA receptor cDNAs, the membranes were striped and reprobed with a ${ }^{32} \mathrm{P}$-labelled $28 \mathrm{~S}$ ribosomal RNA (rRNA) using cDNA as a positive control. The amounts of ET-1, ECE-1, and ETA receptor mRNA are expressed as the ratios of ET-1, ECE-1, or ETA receptor mRNA to $28 \mathrm{~S}$ rRNA.

\section{Statistical methods}

Numerical data are expressed as mean \pm SEM. Statistical analyses of immunohistochemical grading and autoradiographic densitometry were performed by one-way analysis of variance (ANOVA). A p-value of $<0.05$ was considered significant.

\section{Results}

Measurement of ventricular weights revealed the $\mathrm{RV} / \mathrm{LV}+\mathrm{S}$ ratios to be $0.31 \pm 0.03$ in control rats, and $0.33 \pm 0.01,0.36 \pm 0.01,0.38 \pm 0.01$, and $0.61 \pm 0.03$ in rats exposed to hypoxia for $0.5,3,7$, and 14 days, respectively (control versus 7 and 14 days, $\mathrm{p}<0.05$, $\mathrm{n}=4-6$ ). Histological findings of elastic van Gieson staining in rats exposed to hypoxia for 7 and 14 days were also consistent with previous reports of the hypoxic pulmonary hypertension model, that is a gradual increase in medial wall thickness and progressive extension of muscle into smaller arteries [23]. The results indicated that a significant degree of pulmonary hypertension and vascular remodelling developed after 7 and 14 days exposure to hypoxia $(\mathrm{p}<0.05)$.

Northern blot analysis was utilized to detect changes in mRNA expression of ET-1, ECE-1 and ETA receptors in rat lung tissues after exposure to hypoxia (fig. 1). A $2.3 \mathrm{~kb}$ preproET-1 mRNA transcript was expressed in normal and hypoxia-exposed rat lung. Compared with control rats, the ratio of ET-1 mRNAto 28S rRNA was approximately twofold higher after 0.5 days exposure to hypoxia, then decreased after 3 days exposure, and there was a 1.7 and 2.2-fold increase in the ratio after 7 and 14 days exposure, respectively (fig. 2). A $4.4 \mathrm{~kb}$ band for ECE-1 was detected in control and hypoxia-exposed rats lungs (fig. 1). The ratio of ECE-1 mRNA to $28 \mathrm{~S}$ rRNA tended to increase at 0.5 and 3 days, then decrease slightly after 7 and 14 days exposure, but the changes were not statistically significant (fig. 2).

The ETA receptor-specific probe hybridized with 5.2 and $4.3 \mathrm{~kb}$ bands (fig. 1). There was an $80-100 \%$ increase in the ratio of ETA receptor mRNA to $28 \mathrm{~S}$
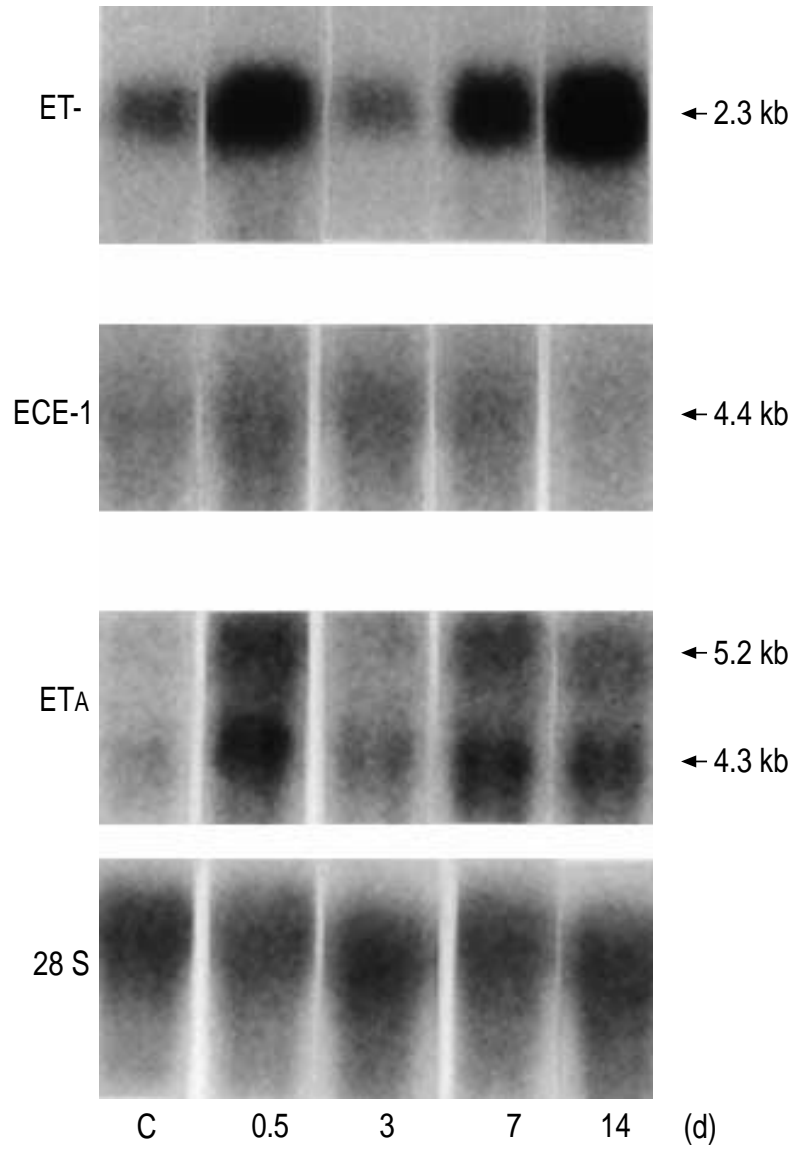

Fig. 1. - Effects of exposure to hypoxia on endothelin (ET)-1, endothelin converting enzyme ECE-1, and ETA receptor (mRNA) in rat lungs. Representative Northern blots of ET-1, ECE-1, and ETA receptors in lung tissue from rats exposed to air and hypoxia for $0.5,3,7$, and 14 days. A $2.3 \mathrm{~kb}$ band for ET-1, $4.4 \mathrm{~kb}$ band for ECE-1, and two bands at 5.2 and $4.3 \mathrm{~kb}$ for ETA receptor were detected in control and hypoxia-exposed lungs.

rRNA after exposure to hypoxia, although transient decrease in the ratio at 3 days was observed (fig. 2).

In normal rat lung, a faint immunoreactivity for big ET-1 was found in the intima of large pulmonary arteries (fig. 3a). A certain amount of big ET-1 immunoreactivity was observed in the intima and media of small pulmonary arteries of $<200 \mu \mathrm{m}$ in ED (fig. 3e). The distribution of big ET-1 along the axial pathway of the pulmonary artery was dominant in the distal segments. Following exposure of rats to hypoxia for 7-14 days, there was an increase in immunoreactivity for big ET-1 in the intima and media of large pulmonary arteries and the media of the small pulmonary arteries (figs $3 \mathrm{~b}$, and $3 \mathrm{f}$, respectively). Big ET-1 appeared to be expressed more preferentially in the media than intima in the small pulmonary artery, which was confirmed by the different pattern of immunostaining for VCAM-1 that is specific for the endothelium (fig. 3g). Semiquantitative analysis showed big ET-1 increased by about three-fold in the pulmonary arteries of $500-1000 \mu \mathrm{m} E D$, and by two-fold in the pulmonary arteries of $60-200 \mu \mathrm{m}$ ED after 7 and 14 days exposure to hypoxia (fig. 4).

Faint immunoreactivity for ECE was found in the 

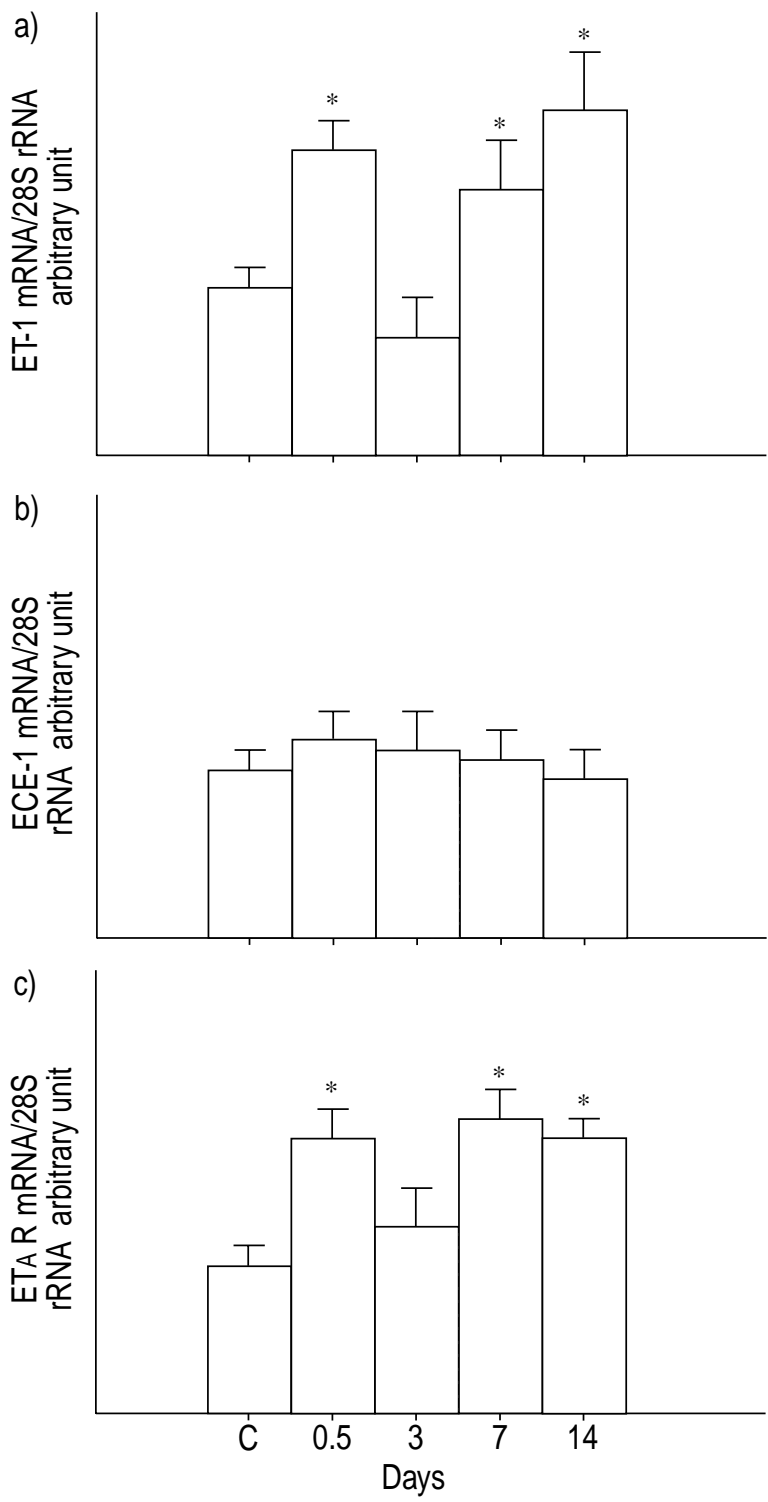

Fig. 2. - Quantitation of endothelin (ET)-1, endothelin converting enzyme (ECE)-1, and ETA receptor messenger ribonucleic acid (mRNA) by densitometry. Data were normalized to allow for variations in RNA loading using a $28 \mathrm{~S}$ ribosomal ribonucleic acid (rRNA) probe. The mRNA from each animal receptor mRNA was increased $0.5,3,7$, and 14 days after exposure to hypoxia $\mathrm{n}=4$ for each group. $*$ : $\mathrm{p}<0.05$ versus control animals.

intima and media of large and small pulmonary arteries in control rats (figs. 5a, c, respectively). The localization of ECE in the pulmonary artery seemed to be different from that of big ET-1; e.g. ECE was expressed more abundantly in the intima than the media. The distribution of ECE seemed to be consistent along the axial pathway of the pulmonary artery in control rats. After exposure to hypoxia for 7 and 14 days, the expression of ECE increased in the intima and media of large and small pulmonary arteries (figs. 5b and d, respectively). The immunoreactivity for ECE was increased by 2.5 -3-fold in the pulmonary arteries of $500-1000, \mu \mathrm{m}$ ED and those of $60-200 \mu \mathrm{m}$ ED after exposure to hypoxia for 14 days (fig. 6). ETA receptors were readily expressed in the media of large pulmonary arteries, while little staining was found in the small pulmonary arteries in control rat lung (fig. 7a and c, respectively). In contrast to big ET-1, the distribution of ETA receptors along the axial pathway of the pulmonary artery was dominant in proximal segments. There was a significant increase in the immunoreactivity for ETA receptors in the distal segments of pulmonary arteries following exposure of rats to hypoxia for 7 and 14 days, whereas no particular change was observed in the proximal segments (figure 7d and b, respectively). The immunoreactivity for ETA receptors was increased 4- and 5-fold in pulmonary arteries of 60-200 $\mu \mathrm{m}$ ED after exposure to hypoxia for 7 and 14 days, respectively (fig. 8).

Immunoreactivity for $\alpha$-SM actin was observed in both large and small pulmonary arteries in a control rat (fig. 9 a and c, respectively). In accordance with the upregulation of big ET-1, ECE, and ETA receptors in the distal segments of pulmonary arteries after exposure to hypoxia, immunoreactivity for $\alpha$-SM actin also increased in the media of pulmonary arteries (fig. 9d). There were progressive increases in immunoreactivity for $\alpha-S M$ actin in the pulmonary arteries of $60-200 \mu \mathrm{m}$ ED and reached by two-fold following the exposure of rats to hypoxia for 14 days, while its expression slightly increased in pulmonary arteries of $500-1000 \mu \mathrm{m}$ ED (fig. 10).

\section{Discussion}

Pulmonary vascular bed is considered to be a main source of ET-1 production in the lung. Although it is generally accepted that ET-1 is mainly produced in vascular endothelial cells, several studies suggested that primary cultured smooth muscle cells isolated from the pulmonary artery expressed and produced ET-1 in vitro $[5,24]$. The study demonstrated that big ET-1 and ECE were co-expressed in vivo in the intima and media of the pulmonary artery under normal and hypoxic conditions. Interestingly, localization of big ET-1 was more prominent in the media rather than in the intima in the distal segments of the pulmonary artery while it was dominant in the intima in the proximal segments. The data revealed that smooth muscle cells, as well as endothelial cells, appear to be an important source of ET-1 in the pulmonary artery. The results are consistent with a recent report that the smooth muscle cells isolate from the pulmonary artery of sheep expressed both ET-1 and ECE [25]. Thus ET-1 synthesis is regulated by synchronous expression and corresponds to the localization of ECE and its substrate big ET-1 in both endothelial cells and smooth muscle cells. Since ET-1 is postulated to act primarily as a local modulator of vascular tone and ET receptors are expressed in endothelial and smooth muscle cells [1, 2], ET-1 synthesized in the pulmonary artery may play both autocrine and paracrine roles in normal conditions and during the development of hypoxic pulmonary hypertension.

Since the pulmonary arterial bed is complex in terms of regional differences in both structure and 

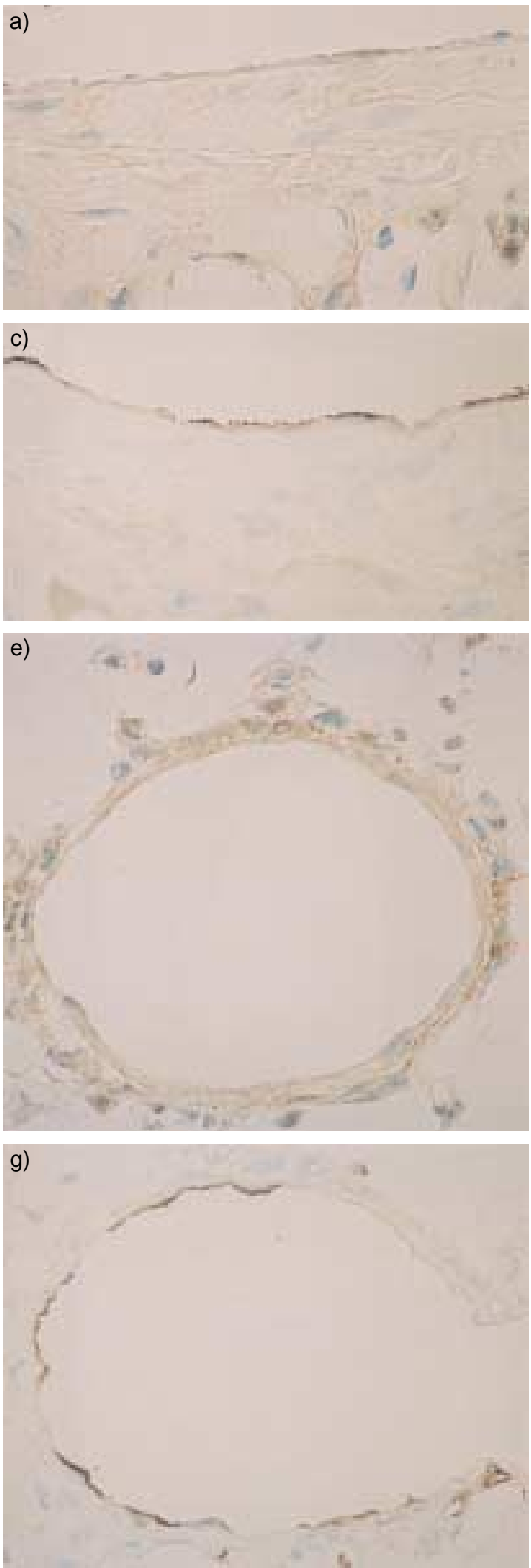

function, it is essential to consider the distribution of ET-1 and their receptors in the pulmonary artery to assess the precise role of the ET system $[1,2,26]$.

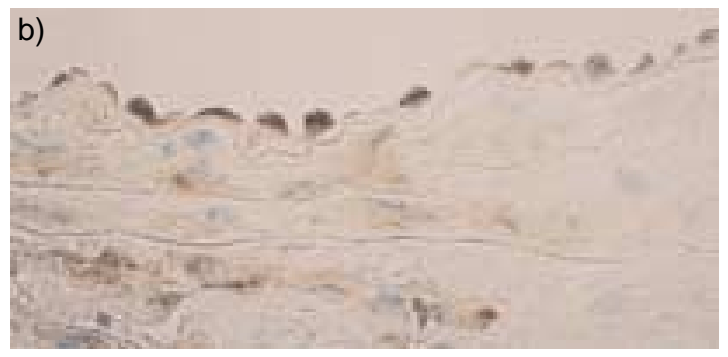

d)
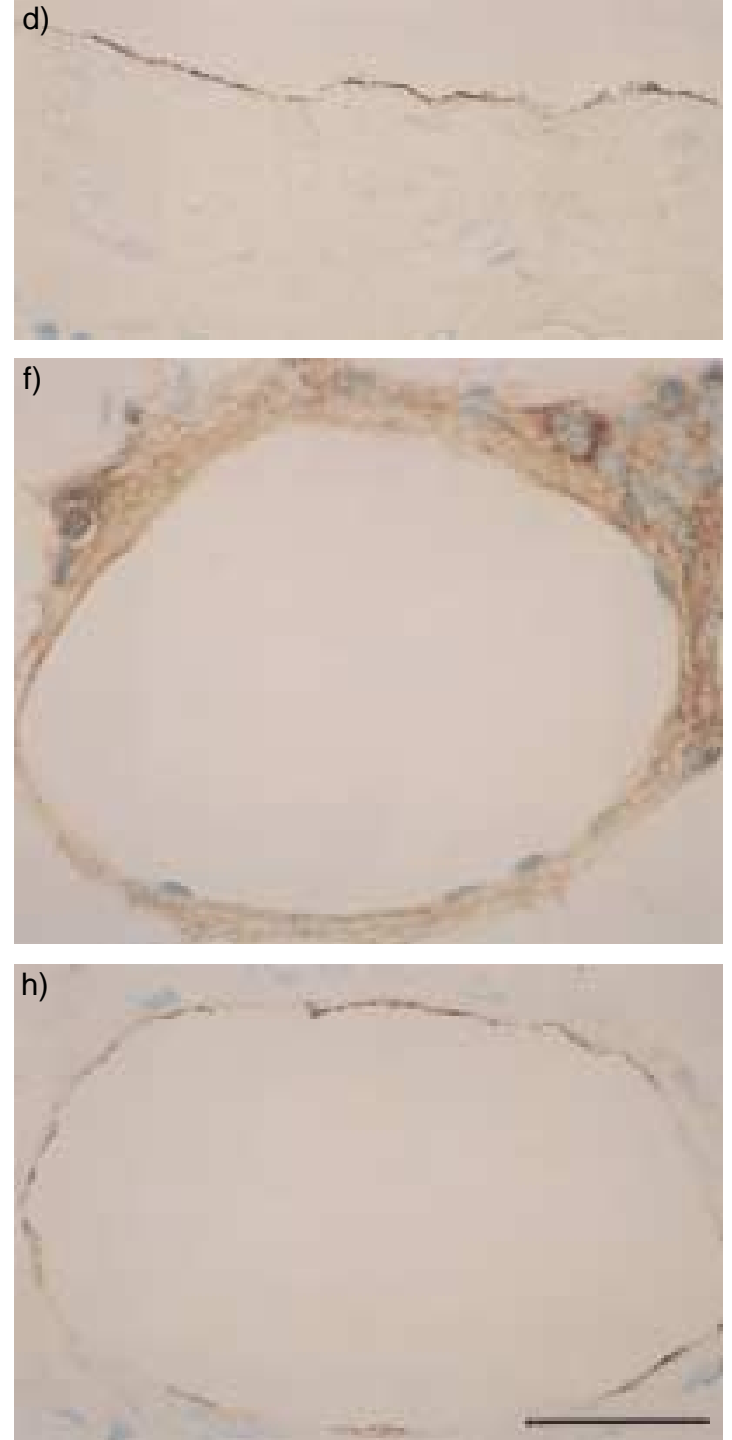

Fig. 3. - A. Representative immunostaining with anti-big endothelin (ET)-1 antibody of pulmonary arteries from a control rat $(\mathrm{a}, \mathrm{e})$ and a rat exposed to hypoxia for 14 days (b, f). Weak staining was detected in the intima and media of a large pulmonary artery (a) and a certain amount of immunoreactivity was found in the distal segment of a pulmonary artery from a control rat (e).

Serial sections of each lung tissue (a, b, e, and f) stained with anti-vascular cell adhesion molecule (VCAM)-1 were shown in panels c, d, g and h, respectively. Counter-staining with methyl green. Internal scale $=30 \mu \mathrm{m}$.

However, there are few studies which pay attention to the distribution of ET-1 along the axial pathway of the pulmonary artery. In the present study, the 


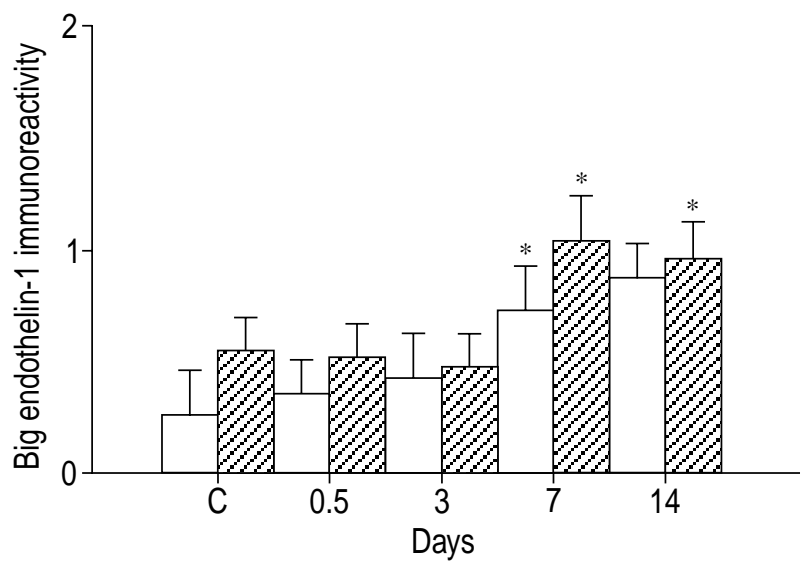

Fig. 4. - Semiquantitative analysis of immunoreactivity for big endothelin (ET)-1 following exposure to hypoxia. Grading of big ET-1 immunoreactivity was increased in the pulmonary arteries of $500-1000 \mu \mathrm{m}$ external diameter (ED) ( $\square$ ), and those of $60-$ $200 \mu \mathrm{m}$ ED $(\mathbb{Z})$ after 7 and 14 days exposure to hypoxia. ${ }^{*}: \mathrm{p}<$ 0.05 versus control animals.

distribution of big ET-1, ECE, and ETA receptors in the pulmonary artery in normal and hypoxic conditions was demonstrated. Together with a previous study by the authors, distribution of big ET-1 and ETA and ETB receptors along the axial pathway of the pulmonary artery is summarized schematically in fig. 11 [4]. In control rats, distribution of big ET-1 was different from that of ETA; big ET-1 was
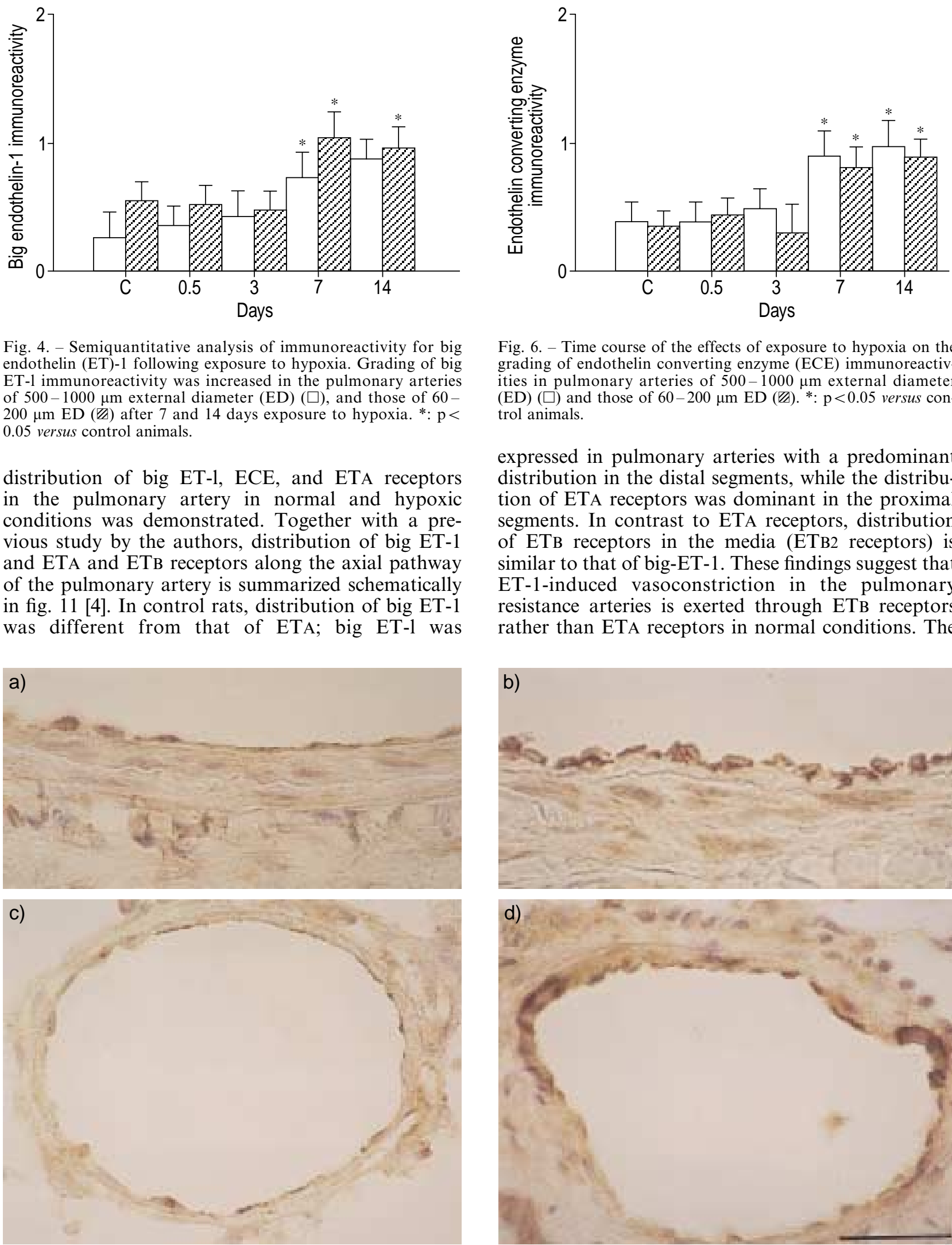

Fig. 6. - Time course of the effects of exposure to hypoxia on the grading of endothelin converting enzyme (ECE) immunoreactivities in pulmonary arteries of $500-1000 \mu \mathrm{m}$ external diameter (ED) $(\square)$ and those of $60-200 \mu \mathrm{m}$ ED $(\mathbb{Z})$. *: $\mathrm{p}<0.05$ versus control animals.

expressed in pulmonary arteries with a predominant distribution in the distal segments, while the distribution of ETA receptors was dominant in the proximal segments. In contrast to ETA receptors, distribution of ETB receptors in the media (ETB2 receptors) is similar to that of big-ET-1. These findings suggest that ET-1-induced vasoconstriction in the pulmonary resistance arteries is exerted through ETB receptors rather than ETA receptors in normal conditions. The
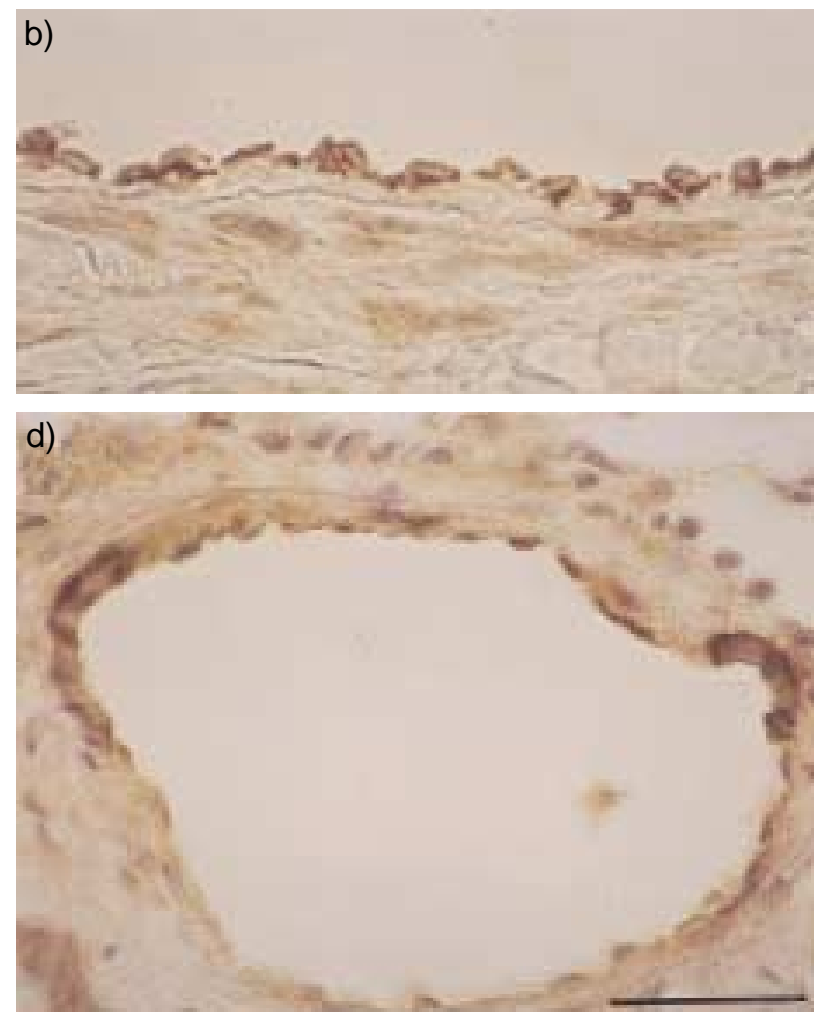

Fig. 5. - Representative photomicrographs of pulmonary arteries from control and hypoxia-exposed rats stained with anti-endothelin converting enzyme (ECE) antibody. Faint staining for ECE was observed in the intima and media of large and small pulmonary arteries in a control rat $(\mathrm{a}, \mathrm{c})$. Fairly strong ECE immunostaining was found in the intima of a large pulmonary artery and media of a small pulmonary artery from a rat exposed to hypoxia for 14 days $(b, d)$. Counter-staining with haematoxyline. Internal scale bar $=30 \mu m$. 

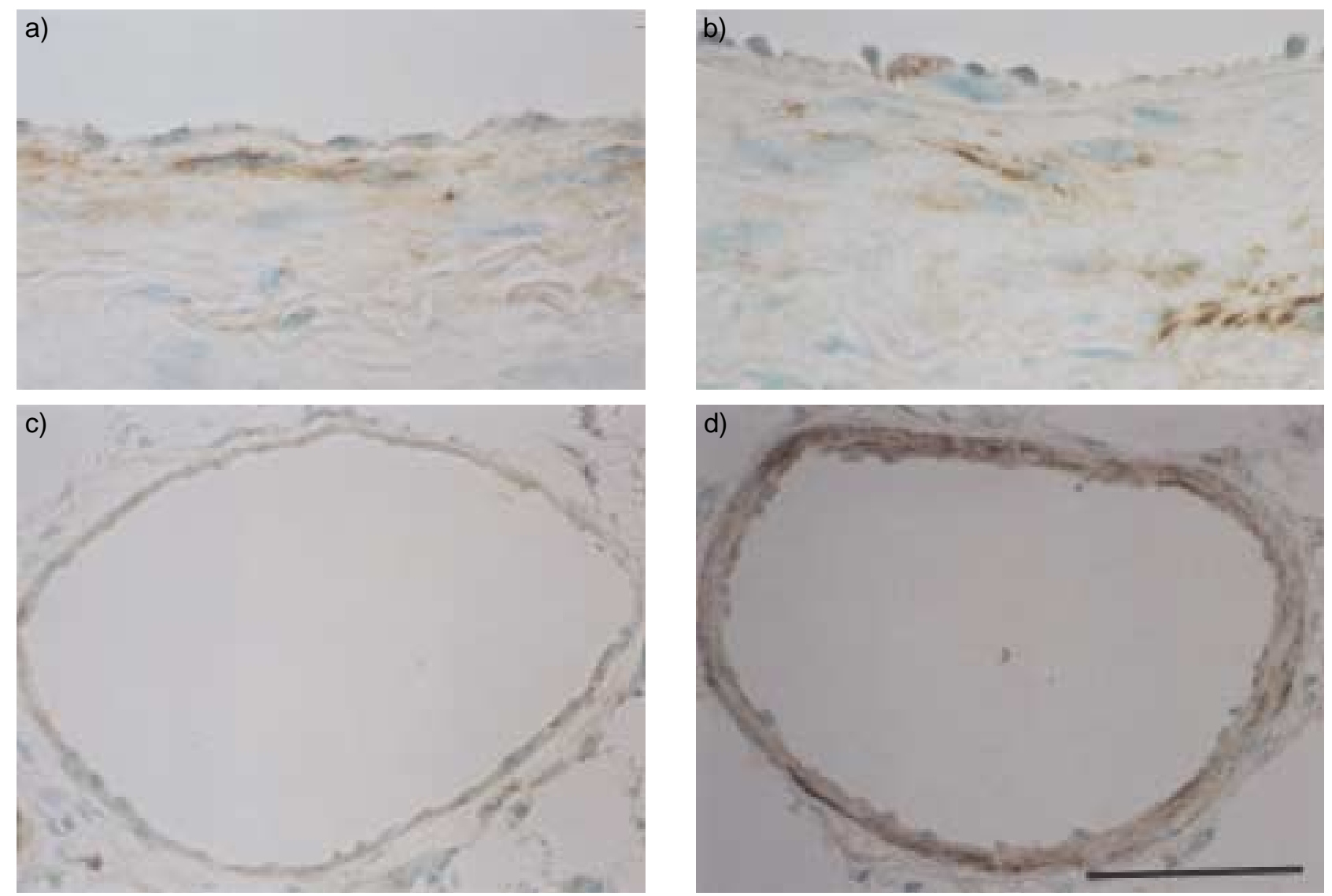

Fig. 7. - A. Representative photomicrographs showing immunostaining with anti-endothelin(ET)A receptor antibody of pulmonary arteries from a control rat $(\mathrm{a}, \mathrm{c})$ and a rat exposed to hypoxia for 14 days $(\mathrm{b}, \mathrm{d})$. Counter-staining with methyl green. Internal scale $\mathrm{bar}=30 \mu \mathrm{m}$.

observation is consistent with the previous pharmacological studies utilizing small pulmonary arteries isolated from normal rats in which ETB receptor agonist is more potent to induce vasoconstriction than ET-1. ETA receptor antagonist had little effects on the ET-1-induced vasoconstriction [1, 27]. Conversely,

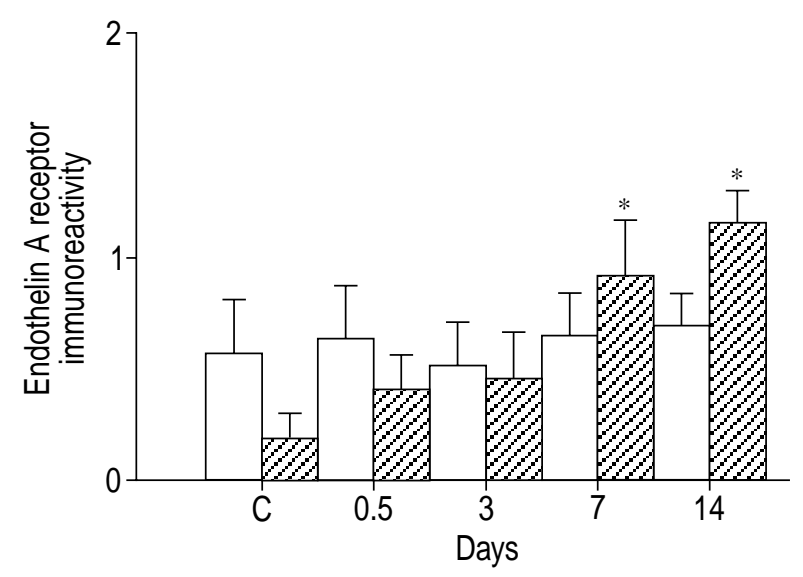

Fig. 8. - Temporal changes in immunoreactivity for endothelin (ET)A receptors after exposure to hypoxia. $\square$ : external pulmonary artery diameter $500-1,000 \mu \mathrm{m}$. $\mathbb{Z}$ : external pulmonary diameter $60-200 \mu \mathrm{m} .{ }^{*}: \mathrm{p}<0.05$ versus control animals.
ETA receptor antagonists prevented ET-1 induced vasoconstriction utilizing the main rat pulmonary artery [28].

The expression of ET-1 and ETA receptor mRNA in the lung increased at 0.5 days exposure to hypoxia and there was a persistent elevation at 7 and 14 days, though a transient decrease of the mRNA expression was detected at 3 days. Although the reason for the drop is not clear, it may reflect a decrease in the expression in nonvascular sites. Furthermore, a part of the changes in ET-1 mRNA expression can be attributed to the elevation of the gene expression by epithelial cells [6]. Recent studies revealed various mechanisms of response to hypoxia. For instance, hypoxia-inducible factor (HIF)-1, a loop-helix-loop transcription factor, transactivates genes encoding proteins such as erythropoietin, vascular endothelial growth factor, and inducible nitric oxide synthase, that participate in homeostatic response to hypoxia. Recently, HIF-1 binding hypoxia responsive element was identified at 5'-flanking sequences of the ET-1 gene [29]. Thus early increase of ET-1 mRNA may be partially induced through HIF-1 response to hypoxia.

Exposure to chronic hypoxia is associated with concomitant increases in the immunoreactivities of big ET-1, ECE, and ETA receptors in the media of small pulmonary arteries. These findings are supported by 

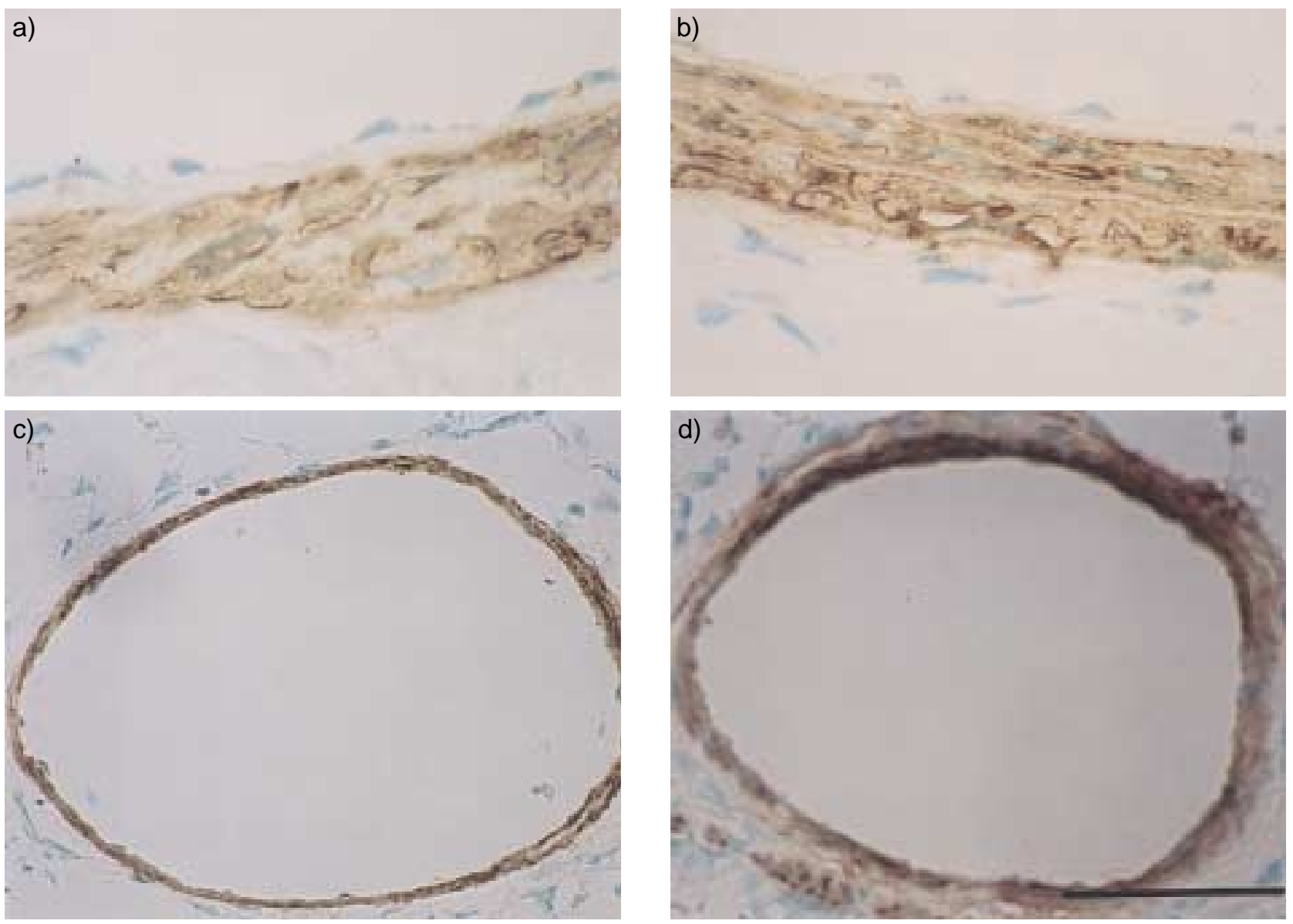

Fig. 9. - Representative photomicrographs of immunostaining with anti- $\alpha$-smooth muscle (SM) actin antibody of pulmonary arteries from a control rat $(a, c)$ and a rat exposed to hypoxia for 14 days $(b, d)$. Counter-staining with methyl green. Internal scale bar $=30 \mu \mathrm{m}$.

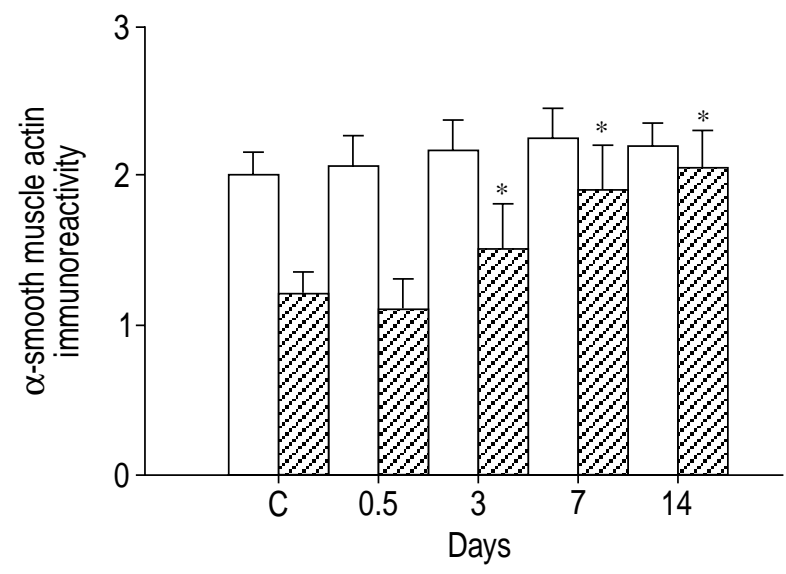

Fig. 10. - Time course of the effects of exposure to hypoxia on the grading of $\alpha$-smooth muscle (SM) actin immunoreactivities in pulmonary arteries of $500-1,000 \mu \mathrm{m}$ external diameter (ED) ( $\square$ ) and those of $60-200 \mu \mathrm{m}$ ED ( $\mathbb{Z})$. Immunostaining for $\alpha$-SM actin was progressively increased in the pulmonary arteries of $60-200 \mu \mathrm{m}$ ED after exposure to hypoxia for 7 and 14 days. *: $\mathrm{p}<0.05$ versus control animals.

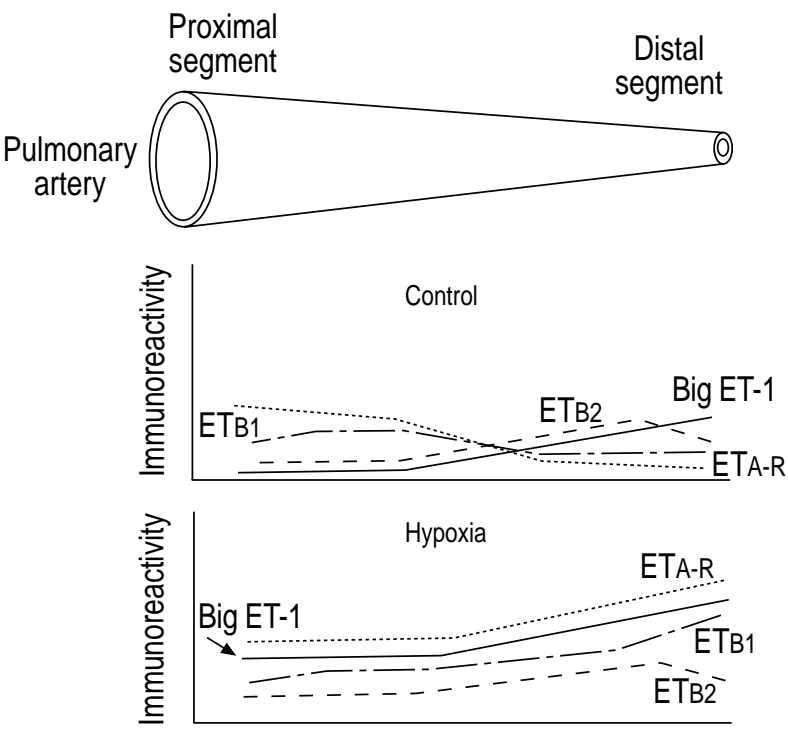

Fig. 11. - Schematic presentation of distribution of big endothelin (ET)-1 (-), ETA receptors $(\cdots \cdots \cdots)$, ETB1 receptors $(---)$, and ЕTв2 receptors (----) along the axial pathway of the pulmonary artery from rats with normal and hypoxic conditions. 
the Northern blot analyses demonstrating persistent increase of the expression of the mRNA expression of ET-1 and ETA receptor after 7 and 14 days exposure to hypoxia. The results suggest that ET-1-induced constrictive action in the pulmonary resistance artery is exerted through ETA receptors rather than ETB2 receptors in hypoxic condition. Furthermore, the increases in big-ET-1 and ECE expression concomitant with ETA receptors in the pulmonary resistance arteries are likely to play an important role in vascular remodelling for the following reasons. First, ET-1 is known to exhibit mitogenic activity for smooth muscle cells through ETA receptors $(1-3)$. Second, as shown in an immunohistochemical study for $\alpha-S M$ actin, spatial localization of both big ET-1 and ETA receptors induced by hypoxia corresponded closely to the site where smooth-muscle cell proliferation primarily occurs after exposure to hypoxia. Finally, temporal profiles of these changes also corresponded with each other. In contrast, despite the upregulation of big ET-1 and ECE in the large pulmonary arteries after exposure to hypoxia, ETA receptors were not significantly increased in smooth muscle cells in the corresponding site [4]. This may be one of the reasons why extent of smooth muscle cell proliferation is less significant in the proximal segments of pulmonary arteries in comparison with the distal segments. Thus, previous reports and the present data suggest that concurrent upregulation of both ET-1 and ETA receptors is crucial for the proliferation of smooth muscle cells in the pulmonary arteries associated with chronic hypoxia. While blockade of ET receptors is known to be an effective treatment for hypoxic pulmonary hypertension, suppression of ET-1 synthesis by an ECE inhibitor may provide another choice for preventing vascular remodelling and the development of pulmonary hypertension associated with chronic hypoxia [30].

Since angiotensin II is an important mediator of vasocostriction and vascular cell growth, local expression of vascular angiotensin converting enzyme (ACE) and angiotensin II AT1 and AT2 receptors may be associated with the development of hypoxic pulmonary hypertension. Marked longitudinal variation in ACE expression along the normal pulmonary vasculature was demonstrated, with the highest levels found in small muscular arteries associated with terminal and respiratory bronchioles [31]. Increased expression of ACE was detected in the endothelium or wall of small muscular arteries in an animal model of hypoxic pulmonary hypertension and clinical cases with primary and secondary pulmonary hypertension [31, 32]. In addition, chronic hypoxia-induced distal muscularization is associated with significant increases in the expression of AT1 and AT2 receptors in a rat experimental model [33]. These observations suggest that the local renin-angiotensin system, as well as ET system, in pulmonary resistance arteries also contributes to the development of hypoxic pulmonary hypertension. Endothelial nitric oxide (NO), another important smooth muscle tone regulator is produced by endothelial NO synthase (eNOS). In normoxic rats, eNOS is expressed in the endothelium of both resistance and conduit pulmonary arteries [34].
Although eNOS expression increases after exposure to hypoxia for 2 days and remained elevated at 7 and 14 days exposure in the conduit artery, the expression progressively increased after 7 and 14 days exposure in resistance arteries $[34,35]$. These findings suggest that up-regulation of eNOS in resistance arteries may modify the ET and renin-angiotensin system mediated vascular remodelling [35].

In conclusion, endothelin-1 is synthesized in the smooth muscle cells as well as endothelial cells in rat pulmonary artery. The distribution of big endothelin-1, endothelin converting enzyme, and endothelin A and $\mathrm{B}$ receptors appears to differ along the axial pathway of the pulmonary artery, and this heterogeneity may play an important role in the regulation of pulmonary circulation under normal and hypoxic conditions.

Acknowledgements. The authors would like to thank K. Tanzawa (Biological Research Laboratories, Sankyo Co, Ltd, Tokyo, Japan) for providing monoclonal anti-ECE antibodies and K. Fukuda (Drug Metabolism and Pharmacokinetics Research Laboratories, Sankyo Co, Ltd.) for advice on immunostaining.

\section{References}

1. Maclean MR. Endothelin-1: a mediator of pulmonary hypertension? Pulm Pharmacol Ther 1988; 11: $125-$ 132.

2. Michael JR, Markewitz BA. Endothelins and the lungs. Am J Respir Crit Care Med 1996; 154: 555-581.

3. Janakidevi K, Fisher MA, Del Vecchio PJ, Tirupathi C, Figge J, Malik AB. Endothelin-1 stimulates DNA synthesis and proliferation of pulmonary artery smooth muscle cells. Am J Physiol 1992; 263 (Cell Physiol 32): C1295-C1301.

4. Soma S, Takahashi H, Muramatsu M, Oka M, Fukuchi Y. Localization and distribution of endothelin receptor subtypes in pulmonary vasculature of normal and hypoxia-exposed rats. Am J Respir Cell Mol Biol 1999; 20: 620-630.

5. Tchekneva E, Quertermous T, Christman BW, Lawrence ML, Meyrick B. Regional variability in prepro-endothelin-1 gene expression in sheep pulmonary artery and lung during the onset of air-induced chronic pulmonary hypertension. J Clin Invest 1998; 101: $1389-1397$.

6. Nakanishi K, Tajima F, Nakata Y, et al. Expression of endothelin-1 in rats developing hypobaric hypoxiainduced pulmonary hypertension. Lab Invest 1999; 79: $1347-1357$.

7. Elton TS, Oparil S, Taylor GR, et al. Normobaric hypoxia stimulates endothelin-1 gene expression in rat. Am J Physiol 1992; 263: R1260-R1264.

8. Li H, Elton TS, Chen YF, Oparil S. Increased endothelin receptor gene expression in hypoxic rat lung. Am J Physiol 1994; 266: L553-L560.

9. Li H, Chen YF, Meng QC, Durand J, Oparil S, Elton TS. Enhanced endothelin-1 and endothelin receptor gene expression in chronic hypoxia. J Appl Physiol 1994; 77: 1451 - 1459 .

10. Golden CL, Kohler JP, Nick HS, Visner GA. Effects of vasoactive and inflammatory mediators on 
endothelin-1 expression in pulmonary endothelial cells. Am J Respir Cell Mol Biol 1995; 12: 503-512.

11. Ivy DD, Le Cras TD, Horan MP, Abman SH. Increased lung preproET-1 and decreased ETBreceptor gene expression in fetal pulmonary hypertension. Am J Physiol 1998; 274: L535-L541.

12. Zamora MA, Dempesey EC, Walchak SJ, Stelzner TJ. BQ123, an ETA receptor antagonist, inhibits endothelin-1-mediated proliferation of human pulmonary artery smooth muscle cells. Am J Respir Cell Mol Biol 1993; 9: 429-433.

13. Bonvallet ST, Zamora MR, Hasunuma $\mathrm{K}$, et al. BQ123, qn ETA-receptor antagonist, attenuates hypoxic pulmonary hypertension in rats. Am J Physiol 1994 266: H1327-H1331.

14. DiCarlo VS, Chen SJ, Meng QC, et al. ETA-receptor antagonist prevents and reverses chronic hypoxiainduced pulmonary hypertension in rat. Am J Physiol 1995; 269: L690 - L697.

15. Le Cras TD, Richter G, Sato K, Abman SH, McMurtry IF. Rapid decrease in lung preproendothelin-1 mRNA in rats with chronic hypoxic pulmonary hypertension after brief exposure to normoxia. $A m$ J Respir Cell Mol Biol 1998; 157: A725.

16. Fulton RM, Hutchinson EC, Jones AM. Ventricular weight in cardiac hypertrophy. Br Heart $J$ 1952; 14: $413-420$

17. Takahashi M, Fukuda K, Shimada K, et al. Localization of rat endothelin-converting enzyme to vascular endothelial cells and some secretory cells. Biochem $J$ 1995; 311: 657-665.

18. Resta TC, Gonzales RJ, Dail WG, Sanders TC, Walker BR. Selective upregulation of arterial endothelial nitric oxide synthase in pulmonary hypertension. Am J Physiol 1997; 272: H888-H896.

19. Takahashi H, Ishidoh K, Muno D, et al. Cathepsin L activity is increased in alveolar macrophages and bronchoalveolar lavage fluid of smokers. Am Rev Respir Dis 1993; 147: 1562-1568.

20. Yanagisawa $\mathrm{M}$, Kurihara $\mathrm{H}$, Kimura $\mathrm{S}$, et al. A novel potent vasoconstrictor peptide produced by vascular endothelial cells. Nature 1988; 332: 411-415.

21. Arai H, Hori S, Aramori I, Ohkubo H, Nakanishi S. Cloning and expression of cDNA encoding an endothelin receptor. Nature 1990; 348: 730-732.

22. Shimada K, Takahashi M, Tanzawa K. Cloning and functional expression of endothelin-converting enzyme from rat endothelial cells. J Biol Chem 1994; 269: $18275-18278$.

23. Hislop A, Reid L. New findings in pulmonary arteries of rats with hypoxia-induced pulmonary hypertension. Br J Exp Pathol 1976; 57: 542 - 554.

24. Zamora MR, Stelzner TJ, Webb S, Panos RJ, Ruff LJ, Dempsey EC. Overexpression of endothelin-1 and growth of pulmonary artery smooth muscle cells from fawn-hooded rats. Am J Physiol 1996; 270: L101L109.

25. Tchecneva E, Lawrence ML, Meyrick B. Cell-specific differences in ET-1 system in adjacent layers of main pulmonary artery. A new source of ET-1. Am J Physiol 2000; 278: L813-L821.

26. Kemp BK, Smolich JJ, Cooks TM. Evidence for specific regional patterns of responses to different vasoconstrictors and vasodilators in sheep isolated pulmonary arteries and veins. Br J Pharmacol 1997; 121: $441-450$

27. McCulloth KM, Docherty C, MacLearn MR. Endothelin receptors mediating contraction of rat and human pulmonary resistance arteries: effect of chronic hypoxia in the rat. Br J Pharmacol 1998; 123: $1621-$ 1630.

28. Bonvallet ST, Oka M, Yano M, Zamora MR, McMurtry IF, Stelzner TJ. BQ-123, anETA receptor antagonist, attenuates endothelin-1 induced vasoconstriction in rat pulmonary circulation. $J$ Cardiovasc Pharmacol 1993; 22: 39-43.

29. $\mathrm{Hu} \mathrm{J}$, Discher DJ, Bishopric NH, Webster KA. Hypoxia regulates expression of the endothelin-1 gene through a proximal hypoxia-inducible factor-1 binding site on the antisense strand. Biochem Biophys Res Commun 1998; 245: 894-849.

30. Takahashi T, Kanada T, Inoue M, et al. Endothelin converting enzyme inhibitor protects development of right ventricular overload and medial thickening of pulmonary arteries in rats with monoclotaline-induced pulmonary hypertension. Life Sci 1998; 63: 137-143.

31. Morrell NW, Atochina EN, Morris KG, Danilov SM, Stenmark KR. Angiotensin converting enzyme expression is increased in small pulmonary arteries of rats with hypoxia-induced pulmonary hypertension. $J$ Clin Invest 1995; 96: $1823-1833$.

32. Orte C, Polak JM, Haworth SG, Yacoub MH, Morrell NW. Expression of pulmonary vascular angiotensin-converting enzyme in primary and secondary plexiform pulmonary hypertension. $J$ Pathol 2000; 192: 379-384.

33. Chassagne C, Eddahibi S, Adamy C, et al. Modulation of angiotensin II receptor expression during development and regression of hypoxic pulmonary hypertension. Am J Respir Cell Mol Biol 2000; 22: $323-332$.

34. Demiryurec AT, Karamsetty MR, McPhaden AR, Wadsworth RM, Kane KA, MacLean MR. Accumulation of nitrotyrosine correlates with endothelial NO synthase in pulmonary resistance arteries during chronic hypoxia in the rats. Pulm Pharmacol Ther 2000; 13: $157-165$.

35. Resta TC, Chicoine LG, Omdahl JL, Walker BR. Maintained upregulation of pulmonary eNOS gene and protein expression during recovery from chronic hypoxia. Am J Physiol 1999; 276: H699-H708. 